\title{
PENGARUH PERBANDINGAN JAGUNG MANIS DAN EDAMAME TERHADAP KARAKTERISTIK SUSU JAGUNG MANIS EDAMAME
}

\author{
The Effect of Ratio Sweet Corn and Edamame to The Characteristic of Sweet Corn Edamame Milk
}

\author{
Jeany Tio Larosta ${ }^{1)}$, Dewa Gde Mayun Permana') I Made Sugitha $^{2)}$ \\ ${ }^{1}$ Mahasiswa Program Studi Ilmu dan Teknologi Pangan, Fakultas Teknologi Pertanian, Universitas Udayana \\ ${ }^{2}$ Dosen Program Studi Ilmu dan Teknologi Pangan, Fakultas Teknologi Pertanian, Universitas Udayana, Kampus \\ Bukit Jimbaran, Badung-Bali
}

\begin{abstract}
This study aimed to determine effect of ratio sweet corn and edamame to characteristic of sweet corn edamame milk, also to know the best ratio from sweet corn and edamame to produce the best characteristic of sweet corn edamame milk. The experimental design used was completely randomized design with different ratio of sweet corn and edamame which consist by 5 level : 300:0, 250:50, 200:100, 150:150, and 100:200. The treatment was repeated 3 times to obtain 15 experimental units. The result of the research show that ratio of sweet corn and edamame had very significant effect on total solid, fat content, protein content, calcium content, viscosity, scoring test, and had no significant effect panelist preference for color, flavor, taste, and overall acceptance. Ratio 150:150 (P3) is the best treatment that produced sweet corn edamame milk with total solid $12.36 \%$, fat content $6.34 \%$, protein content $3.70 \%$, calcium content $243.19 \mathrm{mg} / \mathrm{L}$, and viscosity $613.33 \mathrm{cps}$. The result for sensory test color is yellowish green (liked), flavor is typical edamame (rather liked), taste is typical edamame (rather liked), and overall acceptance is rather liked.
\end{abstract}

Keywords : sweet corn, edamame, corn milk

\section{PENDAHULUAN}

Susu adalah cairan berwarna putih yang disekresikan oleh kelenjar mamae pada mamalia. Susu merupakan bahan makanan yang mengandung protein, lemak, karbohidrat, vitamin dan mineral yang diperlukan oleh tubuh (Winarno, 1993). Menurut Badan Pusat Statistika (2017), konsumsi susu masyarakat Indonesia terbilang rendah atau kisaran 16,5 liter per kapita per tahun. Angka tersebut masih rendah dibandingkan dengan Malaysia (50,9 liter), Thailand (33,7 liter), dan Filipina (22,1 liter) per kapita per tahun (USDA Foreign Agricultural Service, 2016). Konsumsi susu yang rendah di Indonesia dipengaruhi karena produksi susu segar juga masih rendah yaitu 920 ribu ton, sedangkan yang dibutuhkan sebesar 4,5 juta ton/tahun (anon, 2018). Konsumsi susu juga dipengaruhi oleh masyarakat yang tidak bisa menggonsumsi susu sapi segar. Salah satu alasan orang tidak

*Korespondesi Penulis :

E-mail: jeany_tio@yahoo.com ${ }^{1)}$ mengonsumsi susu adalah karena intoleransi laktosa yaitu dimana lambung tidak bisa mencerna gula susu. Konsumsi susu sapi oleh para penderita intoleransi laktosa dapat digantikan dengan mengonsumsi susu nabati yang tidak mengandung laktosa.

Susu nabati merupakan susu yang dibuat dari tumbuhan, terutama dari jenis kacang-kacangan dan serealia. Salah satu bahan yang dapat digunakan sebagai pembuatan susu nabati adalah jagung. Tanaman jagung sendiri memiliki beberapa spesies atau varietas, dalam pembuatan susu jagung biasanya varietas yang digunakan merupakan jagung manis (Zea mays saccharata). Jagung manis memiliki kandungan fruktosa yang lebih besar daripada jagung jenis lainnya, hal ini yang membuat susu jagung manis aman untuk dikonsumsi para penderita diabetes (Tanur, 2009). Jagung manis juga memiliki kandungan serat dan karotenoid sebagai vitamin A (Suarni dan Yasin, 2011), kandungan tersebut merupakan 
pangan fungsional yang baik untuk kesehatan. Jagung manis termasuk komoditas pangan yang mempunyai kadar protein dan kalsium relatif rendah (Suarni dan Widowati, 2016). Kadar protein dan kadar kalsium untuk 100 gram biji jagung manis hanya memiliki 3,5 $\mathrm{g}$ protein dan 3,0 mg kalsium (Iskandar, 2007). Jumlah tersebut merupakan kandungan sebelum diolah mejadi susu jagung manis. Menurut SNI 3141.1:2011 (susu sapi segar) kandungan protein minimum $2,8 \%$ dan menurut SNI 01-3830-1995 (susu kedelai) kandungan protein minimum 2,0\%., sedangkan untuk kadar kalsium susu sapi yaitu $143 \mathrm{mg} / 100 \mathrm{~g}$ atau setara dengan $0,14 \%$ dan susu kedelai yaitu $50 \mathrm{mg} / 100 \mathrm{~g}$ atau setara dengan 0,05 \% (Depkes RI, 1996 dalam Rahmat, 2018). Salah satu usaha untuk meningkatkan kadar protein dan kalsium dari jagung manis adalah dengan mengkombinasikan jagung manis dengan kacang-kacangan.

Pencampuran susu jagung manis dengan kacang - kacangan merupakan perpaduan yang baik untuk melengkapi gizi dari susu jagung manis. Jenis kacang kacangan seperti kacang kedelai merupakan jenis kacang - kacangan yang memiliki protein dan kalsium yang tinggi untuk dapat melengkapi kandungan susu jagung manis. Kacang kedelai memiliki beberapa varietas salah satunya adalah edamame. Menurut Asadi (2009), edamame adalah jenis kedelai yang dipanen saat polongnya masih muda, berwarna hijau, dan saat stadium R6 yaitu pengisian biji penuh pada umur tanaman 7080 hari. Hal ini ditandai terisi penuhnya rongga polong dengan biji hijau. Keadaan tersebut membuat edamame memiliki kadar trypsin inhibitor (antitripsin) yang rendah. Menurut Mahendra dan Oktarina (2017) susu dari edamame memiliki bau dan rasa langu yang lebih sedikit di bandingkan dengan kedelai biasa. Edamame mampu melengkapi nutrisi yang dimiliki oleh jagung manis. Setiap 100 gram kedelai edamame mengandung protein 30,20 g dan kalsium 196 mg (Samsu,2001). Hal tersebut menjadi alasan perlu dilakukan penelitian dengan tujuan mengetahui pengaruh perbandingan jagung manis dan edamame, serta untuk menentukan perbandingan terbaik agar menjadi susu jagung manis edamame dengan karakteristik yang terbaik.

\section{METODE PENELITIAN}

\section{Tempat dan Waktu}

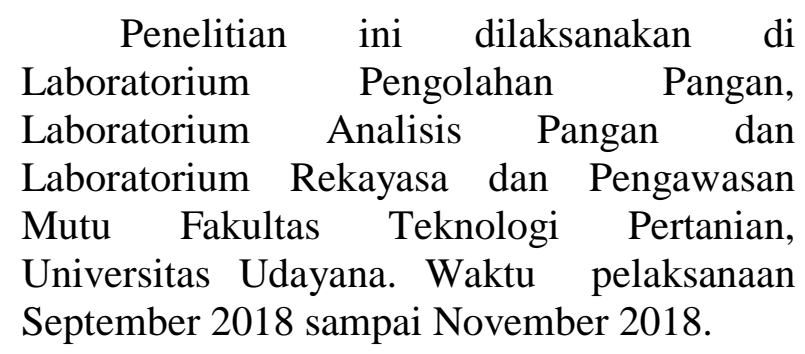

\section{Bahan dan Alat}

Bahan-bahan yang digunakan dalam melaksanakan penelitian ini terdiri dari bahan baku dan bahan kimia. Bahan baku terdiri jagung manis yang diperoleh dari petani jagung di Jalan Sedap Malam Sanur dan kedelai edamame varietas lokal dari Supermarket Tiara Dewata. Bahan pendamping lainnya adalah air minum merk Aqua dan Carboxy Methyl Cellulose (CMC). Bahan kimia yang digunakan dalam melakukan analisis total padatan, protein, lemak dan uji kadar kalsium meliputi alkohol, tablet kjeldahl, $\mathrm{HCl}$, aquades, $\mathrm{H}_{2} \mathrm{SO}_{4}, \mathrm{NaOH}$, asam borat, indikator PP, heksan, dan $\mathrm{CaCO}_{3}$.

Alat yang digunakan untuk membuat susu jagung manis edamame adalah panci, baskom, termometer, kain saring, kompor (Rinnai), timbangan digital (ACIS), sendok pengaduk, blender (Phillips), pisau, talenan dan gelas ukur.

Alat yang digunakan untuk analisis adalah oven (Memmert), alat penyulingan, pemanas listrik, cawan porselin, neraca analitik (Shimadzu), desikator, pompa karet, pinggan penguap, pipet tetes, labu lemak, erlenmeyer (Pyrex), gelas beker (Pyrex), soxhlet, tabung 
reaksi (Pyrex), gelas ukur (Pyrex), kertas saring pembungkus, labu kjeldhal, viskometer (Viscometer Brookfield RV), waterbath (Thermology), dan Spektrofotometer Serapan Atom (Shimadzu).

\section{Rancangan Percobaan}

Percobaan ini menggunakan Rancangan Acak Lengkap (RAL) dengan perlakuan perbandingan jagung manis dan edamame yang terdiri dari 5 taraf, yaitu :

$$
\begin{aligned}
& \mathrm{P} 0=300: 0 \\
& \mathrm{P} 1=250: 50 \\
& \mathrm{P} 2=200: 100 \\
& \mathrm{P} 3=150: 150 \\
& \mathrm{P} 4=100: 200
\end{aligned}
$$

Perlakuan ini diulang sebanyak 3 kali sehingga diperoleh 15 unit percobaan. Data yang diperoleh dianalisis dengan sidik ragam dan apabila perlakuan berpengaruh terhadap variabel yang diamati maka dilanjutkan dengan uji Duncan (Gomez dan Gomez, 1995).

\section{Pelaksanaan Penelitian}

Tabel 1. Formula pembuatan susu jagung manis edamame.

\begin{tabular}{llllll}
\hline \multirow{2}{*}{ Bahan-Bahan } & \multicolumn{3}{c}{ Perlakuan } \\
& P0 & P1 & P2 & P3 & P4 \\
\hline Jagung Manis $(\mathrm{g})$ & 300 & 250 & 200 & 150 & 100 \\
Edamame $(\mathrm{g})$ & 0 & 50 & 100 & 150 & 200 \\
CMC $(\mathrm{g})$ & 0,3 & 0,3 & 0,3 & 0,3 & 0,3 \\
Air $(\mathrm{ml})$ & 600 & 600 & 600 & 600 & 600 \\
\hline
\end{tabular}

Setelah jagung manis dan edamame ditimbang, kemudian di masukkan ke blender dan ditambah air $600 \mathrm{ml}$ dengan suhu $70^{\circ} \mathrm{C}$ lalu diblender selama 10 menit. Setelah jagung manis dan edamame sudah hancur di blender maka akan di hasilkan bubur jagung manis edamame. Bubur jagung manis edamame kemudian disaring dengan kain saring dua lapis untuk mendapatkan filtratnya. Filtrat dari bubur jagung manis edamame kemudian disebut sebagai susu jagung manis edamame namun belum siap untuk di
Proses pelaksanaan penelitian terdiri dari beberapa tahapan yaitu:

1. Perebusan Jagung manis.

Perebusan jagung manis mengikuti penelitian Muhajir, et al (2014) dimodifikasi. Jagung manis disortasi dan dibersihkan kulit dan rambut jagungnya. Kemudian dipipil dan direbus selama 20 menit pada air mendidih $100^{\circ} \mathrm{C}$.. Selanjutnya pipilan jagung manis diangkat dan ditiriskan.

\section{Blansing Edamame.}

Tahap blansing edamame mengikuti metode penelitian Fitriyana (2013) dimodifikasi. Edamame disortasi. Kemudian dipisahkan biji dari kulitnya dan dicuci. Selanjutnya biji edamame di blansing selama 5 menit pada suhu $80^{\circ} \mathrm{C}$. Setelah diblansing biji edamame diangkat dan ditiriskan

3. Pembuatan Susu Jagung Manis Edamame.

Pembuatan Susu jagung manis edamame dilakukan dengan metode Satiarini (2006) dimodifikasi. Jagung manis dan edamame ditimbang sesuai dengan perlakuan pada Tabel 1. konsumsi. Selanjutnya susu jagung manis edamame ditambahkan pengemulsi Carboxy Methyl Cellulosa (CMC) dan diaduk hingga tercampur semua. Susu jagung manis edamame dipasteurisasi menggunakan metode pasteurisasi Setyani (2009). Susu jagung manis edamame yang telah dicampur dengan CMC kemudian di pasteurisasi dengan suhu $\pm 75^{\circ} \mathrm{C}$ selama 10 menit. Setelah dipasteurisasi maka susu jagung manis edamame siap untuk dikonsumsi dan di analisis. 


\section{Parameter yang diamati}

Parameter yang diamati dalam penelitian ini adalah total padatan metode oven (SNI 01-2891-1992), kadar protein metode Kjeldahl (SNI 01-2891-1992), kadar lemak metode hidrolisis ( SNI 01-2891-1992), kadar kalsium metode pengabuan basa dan alat AAS (Apriyantono, 1989), viskositas dengan viscometer Brookfield (LVT), dan evaluasi sensori uji skoring dan kesukaan (Soekarto,1985)

\section{HASIL DAN PEMBAHASAN}

Nilai rata-rata total padatan, kadar lemak, dan kadar protein susu jagung manis edamame dapat dilihat pada Tabel 2 .

Tabel 2. Nilai rata-rata total padatan, kadar lemak, dan kadar protein susu jagung manis edamame.

\begin{tabular}{llll} 
Jagung Manis : Edamame & Total Padatan $(\%)$ & Kadar Lemak $(\%)$ & Kadar Protein $(\%)$ \\
\hline $300: 0$ & $8,85 \pm 0,03 \mathrm{~b}$ & $3,02 \pm 0,42 \mathrm{~d}$ & $1,36 \pm 0,41 \mathrm{c}$ \\
$250: 50$ & $9,60 \pm 0,25 \mathrm{~b}$ & $3,36 \pm 0,49 \mathrm{~d}$ & $2,33 \pm 0,30 \mathrm{bc}$ \\
$200: 100$ & $9,71 \pm 0,40 \mathrm{~b}$ & $5,22 \pm 0,38 \mathrm{c}$ & $2,66 \pm 0,48 \mathrm{~b}$ \\
$150: 150$ & $12,36 \pm 0,78 \mathrm{a}$ & $6,34 \pm 0,52 \mathrm{~b}$ & $3,70 \pm 0,59 \mathrm{a}$ \\
$100: 200$ & $12,12 \pm 0,58 \mathrm{a}$ & $8,44 \pm 0,37 \mathrm{a}$ & $4,51 \pm 0,85 \mathrm{a}$ \\
\hline
\end{tabular}

Keterangan : Nilai rata-rata yang diikuti oleh notasi huruf yang sama pada kolom yang sama menunjukkan tidak berbeda nyata $(\mathrm{P}>0,05)$.

\section{Total Padatan}

Hasil sidik ragam total padatan menunjukkan bahwa perbandingan jagung manis dan edamame berpengaruh sangat nyata $(\mathrm{P}<0,01)$ terhadap total padatan susu jagung manis edamame. Tabel 2 menunjukkan jumlah total padatan terendah susu jagung manis edamame ada pada perlakuan 300:0 yaitu $8,85 \%$, 250:50 yaitu 9,59\%, dan 200:100 yaitu $9,71 \%$. Total padatan tertinggi susu jagung manis edamame diperoleh pada perlakuan 150:150 yaitu $12,36 \%$ dan 100:200 yaitu 12,12\%. Data pada Tabel 6 menunjukkan semakin banyak perbandingan edamame, total padatan susu jagung manis edamame yang dihasilkan semakin besar. Edamame memiliki beberapa kandungan gizi yang lebih besar daripada jagung manis seperti kadar protein $30,20 \mathrm{~g}$ per $100 \mathrm{~g}$ bahan dan kadar karbohidrat 30,1 g per $100 \mathrm{~g}$ bahan (Samsu, 2001). Sedangkan jagung manis memiliki kadar protein $3,5 \mathrm{~g}$ per $100 \mathrm{~g}$ bahan dan karbohidrat 22,8 g per $100 \mathrm{~g}$ bahan (Iskandar, 2007). Hal ini menyebabkan semakin banyak perbandingan edamame maka total padatan pada susu jagung manis edamame akan semakin meningkat. Hasil total padatan ini sesuai dengan penelitian yang dilakukan oleh Setyani et al (2009) dimana total padatan jagung manis dan kacang hijau yang tertinggi di dapat dari jumlah perbandingan yang sama yaitu 1:1. Berdasarkan SNI : (01-3830-1995) total padatan untuk susu kedelai adalah minimal $11,50 \%$. Hasil penelitian yang sesuai dengan SNI terdapat pada perlakuan 150:150 yaitu $12,37 \%$ dan pada perlakuan 100:200 yaitu $12,12 \%$.

\section{Kadar Lemak}

Hasil sidik ragam kadar lemak menunjukkan bahwa perbandingan jagung manis dan edamame berpengaruh sangat nyata $(\mathrm{P}<0,01)$ terhadap kadar lemak susu jagung manis edamame. Data pada Tabel 2 menunjukkan kadar lemak susu jagung manis edamame terendah diperoleh dari perlakuan 300:0 yaitu $3,02 \%$ dan $250: 50$ yaitu $3,36 \%$, sedangkan kadar lemak tertinggi susu jagung manis edamame diperoleh dari perlakuan 100:200 yaitu $8,02 \%$. Hasil penelitian menunjukkan semakin banyak perbandingan edamame pada 
susu jagung manis edamame maka kadar lemak juga semakin meningkat. Hal ini disebabkan kadar lemak edamame yang lebih tinggi dibandingkan jagung manis, sehingga edamame merupakan sumber penyumbang lemak tertinggi. Pada $100 \mathrm{~g}$ bahan, edamame mengandung lemak sebesar 15,6 gr (Samsu,2011), sedangkan jagung manis $1 \mathrm{~g}$ (Iskandar, 2007). Hal ini diperkuat dengan penelitian yang dilakukan oleh Setyani et al (2009), dimana mereka melakukan perbandingan kacang hijau pada susu jagung manis dan terjadi peningkatan kadar lemak dikarenakan kadar lemak kacang hijau yang lebih tinggi. Berdasarkan SNI : (01-38301995) kadar lemak untuk susu kedelai adalah minimal $1,0 \%$. Hasil penelitian menunjukkan semua perlakuan sudah memenuhi SNI (013830-1995).

\section{Kadar Protein}

Hasil sidik ragam kadar protein menunjukkan bahwa perbandingan jagung manis dan edamame berpengaruh sangat nyata $(\mathrm{P}<0,01)$ terhadap kadar protein susu jagung manis. Data pada Tabel 2 menunjukkan kadar protein susu jagung manis edamame berkisar antara $1,36 \%$ sampai dengan $4,51 \%$. Kadar protein susu jagung manis edamame terendah ada pada perlakuan 300:0 yaitu 1,36\%, sedangkan kadar protein tertinggi susu jagung manis edamame tertinggi diperoleh pada perlakuan 150:150 yaitu $3,70 \%$ dan 100:200 yaitu $4,51 \%$. Semakin banyak perbandingan edamame yang dipakai maka semakin tinggi kandungan proteinnya. Hal ini disebabkan karena kandungan protein yang dimiliki oleh edamame lebih tinggi daripada jagung manis. Jagung manis mengandung 3,5 g protein per $100 \mathrm{~g}$ bahan (Iskandar,2007) sedangkan edamame mengandung 30,20 g protein per $100 \mathrm{~g}$ bahan (Samsu, 2001). Hal ini sesuai dengan penelitian yang dilakukan oleh setyani et al (2009) dimana susu jagung manis yang ditambah kacang hijau maka kadar protein akan meningkat. Berdasarkan SNI (01-38301995) kadar protein susu kedelai adalah minimal 2,0\%. Hasil penelitian susu jagung manis edamame yang memenuhi SNI diperoleh dari perlakuan 250 : 50 yaitu $2,33 \%, 200: 100$ yaitu $2,66 \%, 150: 150$ yaitu $3,70 \%$, dan $100: 200$ yaitu $4,51 \%$.

\section{Kadar Kalsium}

Hasil sidik ragam kadar kalsium menunjukkan bahwa perbandingan jagung manis dan edamame berpengaruh sangat nyata $(\mathrm{P}<0,01)$ terhadap kadar kalsium susu jagung manis edamame. Nilai rata-rata kadar kalsium susu jagung manis dapat dilihat pada Tabel

Tabel 3. Nilai rata-rata kadar kalsium dan viskositas susu jagung manis edamame

\begin{tabular}{ccc}
\hline Jagung Manis : Edamame & Kadar Kalsium $(\mathrm{Ca})(\mathrm{mg} / \mathrm{L})$ & Viskositas $(\mathrm{cps})$ \\
\hline $300: 0$ & $26,21 \pm 1,93 \mathrm{~d}$ & $260,00 \pm 20,00 \mathrm{c}$ \\
$250: 50$ & $131,04 \pm 10,95 \mathrm{c}$ & $300,00 \pm 20,00 \mathrm{bc}$ \\
$200: 100$ & $163,67 \pm 7,60 \mathrm{~b}$ & $340,00 \pm 20,00 \mathrm{~b}$ \\
$150: 150$ & $243,19 \pm 22,91 \mathrm{a}$ & $613,33 \pm 23,09 \mathrm{a}$ \\
$200: 100$ & $226,12 \pm 6,96 \mathrm{a}$ & $600,00 \pm 40,00 \mathrm{a}$ \\
\hline
\end{tabular}

Keterangan : Nilai rata-rata yang diikuti oleh notasi huruf yang sama pada kolom yang sama menunjukkan tidak berbeda nyata $(\mathrm{P}>0,05)$.

Tabel 3 menunjukkan bahwa peningkatan kadar kalsium pada susu jagung manis edamame dipengaruhi oleh perbandingan setiap bahan. Perlakuan 300:0 yaitu 26,21 $\mathrm{mg} / \mathrm{L}$ memiliki kandungan kalsium terendah. Kadar kalsium tertinggi ada pada perlakuan 150:150 yaitu $243,19 \mathrm{mg} / \mathrm{L}$ dan 100:200 yaitu 226,12 mg/L., semakin banyak edamame yang ditambahkan maka kadar kalsium semakin meningkat. Menurut 
Iskandar (2007) Jagung manis memiliki kadar kalsium sebanyak 3,0 mg/100 g bahan, sedangkan edamame memiliki kadar kalsium sebanyak 196 mg/100 g bahan (Samsu,2001) karena kadar kalsium edamame lebih besar maka edamame menjadi penyumbang kalsium dalam susu jagung manis edamame. Hal ini yang menyebabkan semakin besar perbandingan edamame maka kadar kalsium susu jagung manis edamame juga semakin meningkat. Hasil penelitian ini didukung oleh penelitian yang dilakukan oleh Ambarwani et al (2016) yang melakukan perbandingan susu kedelai dengan wijen sangrai giling dimana wijen memiliki kadar kalsium lebih besar dan meningkatkan kadar kalsium susu kedelai. Meskipun telah terjadi peningkatan kalsium namun hasil penelitian menunjukkan bahwa kadar kalsium susu jagung manis edamame belum dapat setara dengan kalsium susu sapi maupun susu kedelai yaitu untuk susu sapi $143 \mathrm{mg} / 100 \mathrm{~g}$ dan susu kedelai $50 \mathrm{mg} / 100 \mathrm{~g}$ (Depkes RI 1996, dalam Rahmat 2018).

\section{Viskositas}

Hasil analisis ragam untuk viskositas menunjukkan bahwa perbandingan jagung manis dan edamame berpengaruh sangat nyata $(\mathrm{P}<0,01)$ terhadap viskositas susu jagung manis edamame. Nilai rata-rata viskositas susu jagung manis dapat dilihat pada Tabel 3.

Hasil analisis viskositas berkisar antara 260,00 cps-613,33 cps. Semakin banyak edamame yang di tambahkan semakin tinggi viskositasnya. Viskositas terendah ada pada perlakuan 300:0 yaitu 260,00 cps. Viskositas tertinggi ada pada perlakuan 150:150 yaitu 613,33 cps dan 100:200 yaitu 600,00 cps.
Viskositas dipengaruhi oleh komponen terlarut dari jagung manis dan edamame. Karbohidrat jagung manis lebih didominasi oleh kandungan gula daripada pati (Suarni dan Widowati, 2016) sedangkan edamame memiliki karbohidrat kompleks yaitu kandungan pati. Pati sangat mempengaruhi viskositas karena pati dapat mengalami gelatinisasi bila mendapatkan perlakuan panas (Winarno, 1997) Edamame miliki karbohidrat yang lebih besar yaitu 30,1 g/100 g bahan (Samsu, 2001) sedangkan jagung manis 22,8 $\mathrm{g} / 100 \mathrm{~g}$ bahan (Iskandar, 2007). Hal ini yang menyebabkan semakin banyak perbandingan edamame maka viskositas yang dihasilkan juga semakin besar. Kandungan dari jagung manis dan edamame akan diikat oleh emulsifier yaitu CMC. Menurut Koswara (1992), susu nabati yang mengandung banyak protein akan lebih kental dan membentuk gumpalan saat dipanaskan bila kadar proteinnya $>7 \%$, sehingga kurang disukai. Nilai viskositas susu jagung manis edamame dari semua perlakuan dapat diterima karena kadar proteinnya hanya berkisar antara $1,36 \%-4,51 \%$.

\section{Sifat Sensoris}

Uji sifat sensoris dilakukan dengan uji hedonik terhadap warna, aroma, rasa dan penerimaan keseluruhan lalu dilakukan uji skoring dilakukan terhadap warna, aroma, dan rasa. Nilai rata-rata uji hedonik terhadap warna, aroma, rasa dan penerimaan keseluruhan susu jagung manis edamame dapat dilihat pada Tabel 5. Nilai rata-rata uji skoring warna, aroma, rasa susu jagung manis edamame dapat dilihat pada Tabel 6. 
Tabel 5. Nilai rata - rata uji hedonik warna, aroma, rasa, dan penerimaan keseluruhan susu jagung manis edamame.

\begin{tabular}{lllll}
\hline Jagung Manis : Edamame & Warna & Aroma & Rasa & $\begin{array}{l}\text { Penerimaan } \\
\text { Keseluruhan }\end{array}$ \\
\hline $300: 0$ & $5,4 \mathrm{a}$ & $5,9 \mathrm{a}$ & $5,7 \mathrm{a}$ & $6,2 \mathrm{a}$ \\
$250: 50$ & $5,3 \mathrm{a}$ & $5,9 \mathrm{a}$ & $5,6 \mathrm{a}$ & $6,2 \mathrm{a}$ \\
$200: 100$ & $5,5 \mathrm{a}$ & $5,5 \mathrm{a}$ & $5,5 \mathrm{a}$ & $6,0 \mathrm{a}$ \\
$150: 150$ & $5,7 \mathrm{a}$ & $5,3 \mathrm{a}$ & $5,2 \mathrm{a}$ & $5,5 \mathrm{a}$ \\
$200: 100$ & $5,7 \mathrm{a}$ & $5,3 \mathrm{a}$ & $5,4 \mathrm{a}$ & $5,7 \mathrm{a}$ \\
\hline
\end{tabular}

Keterangan : - Nilai rata-rata yang diikuti oleh notasi huruf yang sama pada kolom yang sama menunjukkan tidak berbeda nyata $(\mathrm{P}>0,05)$.

- Kriteria hedonik : 1 (sangat tidak suka); 2 (tidak suka); 3 (agak tidak suka); 4 (Biasa); 5 (agak suka); 6 (suka); 7 (sangat suka).

Tabel 6. Nilai rata-rata uji skoring warna, aroma, dan rasa susu jagung manis edamame

\begin{tabular}{llll}
\hline Jagung Manis : Edamame & Warna $^{1)}$ & Aroma $^{2)}$ & Rasa $^{2)}$ \\
\hline P0 & $4,6 \mathrm{a}$ & $4,5 \mathrm{a}$ & $4,3 \mathrm{a}$ \\
P1 & $3,6 \mathrm{~b}$ & $4,1 \mathrm{a}$ & $3,7 \mathrm{~b}$ \\
P2 & $2,6 \mathrm{c}$ & $2,9 \mathrm{~b}$ & $2,7 \mathrm{c}$ \\
P3 & $1,7 \mathrm{~d}$ & $2,1 \mathrm{c}$ & $2,1 \mathrm{~d}$ \\
P4 & $1,0 \mathrm{e}$ & $1,7 \mathrm{c}$ & $1,7 \mathrm{~d}$ \\
\hline
\end{tabular}

Keterangan : Nilai rata-rata yang diikuti oleh notasi huruf yang sama pada kolom yang sama menunjukkan tidak berbeda nyata $(\mathrm{P}>0,05)$.

${ }^{1)}$ Kriteria skoring warna : 1 (hijau), 2 (hijau kekuningan), 3 (kuning kehijauan), 4 (kuning), 5 (kuning tua).

${ }^{2)}$ Kriteria skoring aroma dan rasa : 1 (sangat khas edamame), 2 (khas edamame), 3 (tidak ada rasa yang dominan), 4 (khas jagung manis), 5 (sangat khas jagung manis).

\section{Warna}

Hasil sidik ragam pada uji skoring minuman susu jagung manis edamame menunjukkan bahwa perbandingan jagung manis dan edamame berpengaruh sangat nyata $(\mathrm{P}<0,01)$. Pada tabel 6 menunjukkan bahwa susu jagung manis edamame yang memiliki perbandingan jagung manis lebih banyak akan cenderung berwarna kuning karena mengandung karotenoid yang memberikan warna kuning pada jagung manis (Suarni dan Widowati, 2016), sedangkan susu jagung manis edamame yang memiliki perbandingan edamame lebih banyak akan cenderung berwarna hijau karena edamame mengandung klorofil yang memberikan warna hijau (Amar dan Dewi, 2013).

Pada uji hedonik warna susu jagung manis edamame hasil sidik ragam menunjukkan bahwa perbandingan jagung manis dan edamame tidak berpengaruh nyata $(\mathrm{P}>0,05)$. Hal ini ditunjukkan pada tabel 5 dimana nilai rata-rata uji hedonik warna berkisar antara 5,3 (agak suka) sampai dengan
5,7 (suka). Notasi pada setiap perlakuan tidak berbeda nyata menunjukkan panelis rata-rata menyukai warna dari seluruh perlakuan. Hal ini menunjukkan bahwa perbedaan warna dari setiap perlakuan masih bisa diterima oleh panelis. Menurut Winarno (1997), secara visual faktor warna tampil lebih dahulu dan kadang-kadang sangat menentukan sebelum faktor lain dipertimbangkan.

\section{Aroma}

Hasil sidik ragam pada uji skoring susu jagung manis edamame menunjukkan bahwa perbandingan jagung manis dan edamame berpengaruh sangat nyata $(\mathrm{P}<0,01)$. Tabel 6 menunjukkan bahwa nilai rata-rata uji skoring berkisar antara 1,7 (khas edamame) sampai dengan 4,5 (khas jagung manis). Menurut Fellow (1998), aroma dalam bahan makanan dapat ditimbulkan oleh komponen-komponen volatil, akan tetapi komponen volatil tersebut dapat hilang selama proses pengolahan terutama panas. 
Pada uji hedonik aroma susu jagung manis edamame hasil sidik ragam menunjukkan bahwa perbandingan jagung manis dan edamame tidak berpengaruh nyata $(\mathrm{P}>0,05)$. Hal ini ditunjukkan pada tabel 5 dimana nilai rata-rata uji hedonik aroma berkisar antara 5,3 (agak suka) dampai dengan 5,9 (suka). Notasi pada setiap perlakuan tidak berbeda nyata menunjukkan panelis rata-rata menyukai aroma dari seluruh perlakuan yang diuji. Melalui hal tersebut disimpulkan bahwa perbedaan aroma pada setiap perlakuan masih dapat diterima oleh panelis.

\section{Rasa}

Hasil sidik ragam pada uji skoring susu jagung manis edamame menunjukkan bahwa perbandingan jagung manis dan edamame berpengaruh sangat nyata $(\mathrm{P}<0,01)$. Tabel 6 menunjukkan bahwa nilai rata-rata uji skoring berkisar antara 1,7 (khas edamame) sampai dengan 4,3 (khas jagung manis). Susu jagung manis edamame yang memiliki perbandingan jagung manis lebih banyak akan cenderung terasa manis karena kandungan gula pada jagung manis.

Pada uji hedonik rasa susu jagung manis edamame hasil sidik ragam menunjukkan bahwa perbandingan jagung manis dan edamame tidak berpengaruh nyata $(\mathrm{P}>0,05)$. Hal ini ditujukkan pada tabel 5 dimana nilai rata-rata uji hedonik berkisar antara 5,2 (agak suka) sampai dengan 5,6 (suka). Notasi pada setiap perlakua tidak berbeda nyata meunjukkan panelis rata-rata menyukai rasa dari seluruh perlakuan yang diuji. Perbedaan rasa dari setiap perlakuan masih dapat diterima oleh panelis sehingga notasi tidak berbeda nyata.

\section{Penerimaan Keseluruhan}

Hasil sidik ragam penerimaan keseluruhan susu jagung manis edamame menunjukkan bahwa perbandingan jagung manis dan edamame tidak berpengaruh nyata
$(\mathrm{P}>0,05)$. Tabel 5 menunjukkan bahwa nilai rata-rata uji hedonik terhadap penerimaan keseluruhan susu jagung manis edamame berkisar antara 5,5 (suka) sampai dengan 6,2 (suka). Notasi pada uji penerimaan keseluruhan tidak berbeda nyata pada setiap perlakuan yang diuji sehingga hal tersebut menunjukkan bahwa susu jagung manis edamame dapat diterima dengan cukup baik oleh panelis. Penerimaan keseluruhan susu jagung manis edamame dipengaruhi oleh beberapa faktor seperti warna, aroma dan rasa.

\section{KESIMPULAN DAN SARAN}

\section{Kesimpulan}

Berdasarkan hasil penelitian ini dapat disimpulkan sebagai berikut :

1. Perbandingan jagung manis dan edamame berpengaruh terhadap total padatan, kadar lemak, kadar protein, kadar kalsium, viskositas, dan uji skoring. Perbandingan jagung manis dan edamame tidak berpengaruh nyata terhadap uji hedonik susu jagung manis edamame.

2. Perbandingan jagung manis dan edamame menghasilkan susu jagung manis edamame dengan karakteristik terbaik pada perbandingan 150:150 (P3) dengan hasil total padatan $12,36 \%$, kadar lemak 6,34\%, kadar protein $3,70 \%$, kadar kalsium 243,19 $\mathrm{mg} / \mathrm{L}$, dan viskositas 613,33 cps. Hasil uji sensoris warna adalah hijau kekuningan disukai, aroma adalah khas edamame agak disukai, rasa adalah khas edamame agak disukai, dan penerimaan keseluruhan adalah agak disukai.

\section{Saran}

Berdasarkan hasil penelitian sebaiknya dalam pembuatan susu jagung manis edamame dibuat dengan perbandingan pada perlakuan $1: 1$ 


\section{DAFTAR PUSTAKA}

Anonimus. 1992. SNI (Standar Nasional Indonesia) 01-2891-1992 Tentang Cara Uji Makanan dan Minuman. BSN (Badan Standar Nasional). Jakarta.

Anonimus. 1995. SNI (Standar Nasional Indonesia) 01-3830-1995 Tentang Susu Kedelai. BSN (Badan Standar Nasional). Jakarta.

Anonimus.2011.SNI 31-411-2011 Tentang Susu Segar-Bagian 1 : Sapi.

Anonimus.2016. Konsumsi Susu Masih 11,09 Liter per Kapita. Kementrian Perindustrian Republik Indonesia. http://www.kemenperin.go.id/artikel/ 8890/Konsumsi-Susu-Masih-11,09Liter-per-Kapita. Diakses pada 16 Mei 2018.

Amar, W.S. dan Dewi. 2013. Pengaruh penggunaan minyak kedelai dan susu skim terhadap sifat organoleptik pasta kedelai edamame. Ejournal boga 1:139-149.

Ambarwati, K., Pramudya, dan F. Mustikaningrum. 2016. Pengaruh perbandingan kedelai dengan wijen sangrai giling terhadap kadar kalsium susu kedelai. Jurnal Kesehatan 1:19-24.

Asadi. 2009. Identifikasi ketahanan sumber daya genetik kedelai terhadap hama penghisap polong. Bul. Plasma Nutfah. 15(1):27-32.

Fitriyana, N. I. 2014. Pengembangan Pangan Fungsional Antikolesterol Dari Kedelai Edamame (Glycine max L. Merril). Skripsi. Tidak dipublikasikan. Universitas Jember. Jember.

Gomez, K.A. dan A. A. Gomez.1995. Prosedur Statistik Untuk Penelitian
Pertanian. (Terjemahan). E. Syamsudin dan J. S. Baharsjah. Universitas Indonesia. Jakarta.

Iskandar D. 2007. Pengaruh dosis pupuk N, P dan $\mathrm{K}$ terhadap pertumbuhan dan produksi tanaman jagung manis di lahan kering. J Sains dan Teknologi, 30: 26-34.

Mahendra, Y. dan Oktarina. 2017. Respon Kedelai Edamame (Glycine max, L Merill) Terhadap Waktu Aplikasi dan Konsentrasi Pestisida Nabati Gadung.

Muhajir, R., A. Rahim, dan S.G. Hutomo. 2014. Karakteristik Fisik Dan Kimia Susu Jagung Manis Pada Berbagai Lama Perebusan. Skripsi. Tidak dipublikasikan. Universitas Tadulako. Palu.

Naga, W. S., A. Berlian, S.R. Ery, dan A. Aning. 2010. Koagulasi protein dari ekstrak biji kecipir dengan metode pemanasan. Jurnal Widya Teknik 9:1-11

Oka, B., W. Mohammad, dan Kadirman. 2017. Karakteristik kimia susu sapi perah di kabupaten sinjai. Jurnal Pendidikan Teknologi Pertanian 3:195-202.

Purwanto, A. 2006. Pengaruh Jenis Penstabil dan Konsentrasi Shortening Terhadap Kualitas Es Krim Ubi Jalar Ungu Jepang. Skripsi. Tidak dipublikasikan. Universitas Brawijaya, Malang

Samsu, S. 2001. Membangun Agroindustri Bernuansa Ekspor Edamame (Vegetable soybean). Jakarta: PT Mitra Tani Dua Tujuh.

Satriarini dan Bertha. 2006. Kajian Produksi Dan Profitabilitas Pembuatan Susu Jagung. Skripsi. Tidak 
dipublikasikan. Fakultas Teknologi Pertanian. IPB. Bogor.

Setyani, S. Medikasari. dan W. I. Astuti. 2009. Fortifikasi jagung manis dan kacang hijau terhadap sifat fisik, kimia, dan organoleptik susu jagung manis kacang hijau. Jurnal Teknologi Industri dan Hasil Pertanian 14:2

Suarni dan Yasin. 2011. Jagung sebagai sumber pangan fungsional. Jurnal Iptek Tanaman Pangan.

Suarni dan Widowati. 2016. Struktur, komposisi, dan nutrisi jagung. Balai Penelitian Tama Serealia. Bogor

Tanur, A. E. 2009. Pengaruh Proporsi Kedelai : Jagung Manis Terhadap Sifat Fisikokimia dan Organoleptik Minuman Sari Kedelai Jagung Manis. Surabaya. Skripsi. Tidak dipublikasikan. Fakultas Teknologi Pertanian Universitas Katolik Widya Mandala Surabaya.

Winarno, F.G. 1993. Pangan, Gizi, Teknologi dan Konsumen. PT Gramedia Pustaka Utama. Jakarta.

Winarno, F.G.1997. Kimia Pangan dan Gizi. PT Gramedia Pustaka Utama. Jakarta. 